\title{
JOB ANALYSIS AS A CROSS-SECTION FUNCTION OF HUMAN RESOURCE MANAGEMENT
}

\section{Katarína Stachová}

School of Economics and Management in Public Administration in Bratislava, Bratislava, Slovak Republic

\author{
(C) MESTE NGO
}

JEL Category: J2, J28, 01, 015

\begin{abstract}
Job analysis is the key function of human resource management, which results from the crosssectional character of this function, i.e. it has a direct impact on organisational structure formation and subsequent human resources planning in organisations. The essential fact related to job analysis is its need to carry it out before any activity from the sphere of human resource management functions, since its result has a significant impact on all these functions. It is therefore necessary to summarize the information collected from job analysis in the form of job description and job requirements specification, and ensure their practical implementation in the organisation. Questionnaire research we conducted at School of Economics and Management in Public Administration in Bratislava over the last two years was focused on finding out whether and in what extent organizations operating in Slovakia focus on job analysis, as comprehensive focus of organisations on job analysis is substantial. The research implied that approximately $40 \%$ of the interviewed organisations do not carry out job analyses at all, while relation comparison implies a significant influence between the size of organisation and job analysis execution.
\end{abstract}

Keywwords: job analysis, cross-section function, organisations operating in the Slovak Republic, human resource management

\section{INTRODUCTION}

Human resources in an organisation represent the whole human potential. It comprises not only

The address of the author:

Katarína Stachová

莑三” katarina.stachova@vsemvs.sk the number and structure of employees but also aspects like education and culture, interpersonal relationships, ability to cooperate, perception of social and ecological factors of the environment, etc. Systematic creation and usage of human potential is a precondition of building and development of strengths and competitive 
advantages of an organisation. That is all possible only on the grounds of systemically framed human resource management orientating employees so that they achieve essential strategic aims and objectives of their organisation (Kachaňáková, 2011).

Working potential of organisations is most significantly influenced by how the department of human resource management, personnel department, personnel professional, respectively employee in charge of human resource management can fulfil two following essential tasks (Kachaňáková, 2011):

- ensuring of a necessary number of employees in requested professional and qualification structures and in dynamic compliance with strategic objectives of the given organisation,

- harmonisation of employee behaviour with strategic objectives of the organisation.

Effective fulfilment of these tasks requires a broad range of various activities denoted as human resource management functions. These essential functions include job analysis, recruitment and selection of employees, distribution of employees, education and development of employees, career management and talent management, evaluation of performance, remuneration of employees, working relationships and working conditions. Our research analysed how and to what intension organisations operating in Slovakia focus on individual functions. This contribution will present results of the research focused on job analysis.

Priority focus within human resource management functions needs to be on job analysis, since within its scope the organisation ensures systematic collection and evaluation of information on job content, conditions of its performance and requirements imposed on people occupying these positions as well updating of all information, and it is also a basis upon ensuring of other human resource management functions (Blštáková 2009).

In order to justify comprehensive focus of organisations on job analysis, the questionnaire research we conducted at School of Economics and Management in Public Administration in Bratislava over the last three years was focused on finding out whether and in what extent organisations operating in Slovakia focus on job analysis.

\section{JOB ANALYSIS}

Job analysis can generally be characterized as a systematic process of collection, evaluation and summarization of information on individual works and preconditions of their performance. The objective of job analysis is to collect information on tasks, methods, duties, rights and connections to other horizontally and diagonally related positions within organisational structure, as well as to get information on the need and level of physical and psychical dispositions of the employee who will occupy the given position. It is subsequently necessary to evaluate collected information from the viewpoint of present needs and strategy of the organisation and, what many organisations forget about, from the viewpoint of present technologies which can not only significantly facilitate work but also decrease its time demand. Collected information needs to be summarized in the form of job description and specification of requirements on the given employee, and its implementation in performance of the given work thus needs to be ensured.

Job description can be characterized as a written report including, besides essential overview, purpose and objective of the work, individual spheres of activities and responsibilities creating the job content or also social and physical nature of surrounding environment. It is normally expressed by the way of behaviour, i.e. what a person does, what abilities they use in performance of their work, judgements they make and factors they take into consideration in doing so. Organisational conditions and the way of work performance of successful employees have a major impact on the job description. The job description should provide reasons for activity and behaviour of the given employee, i.e. it has to be clear on its basis what the given person at the given position does and by what means. It also determines the amount of working time necessary to fulfil individual activities, duties the employee has to fulfil sporadically, or whether a risk occurs upon the work performance. On the grounds of elaborated job description, a type of person suitable for the given work is determined, 
i.e. specification of requirements on the employee is elaborated (Kachaňáková, 2011).

Specification of requirements on the employee, respectively on the jobholder can be characterized as a written report formulating the profile of competent person (professional, social and emotional competence) regarding performance of the given work. It is a profile of human abilities and qualities, including e.g. education, specific abilities, practical experience (general, professional), physical and psychical preconditions of the work performance, dispositions, interests, etc. Upon its elaboration, it is necessary to be aware of the fact that it is supposed to specify requirements on an employee, not to describe an ideal employee. For this reason, it is appropriate to formulate such requirements as basic and preferred (Kravčáková, 2011).

Justification of job analysis mainly results from the fact that job analysis is a cross-section function of human resource management, which means that it has a direct impact on organisational structure creation and subsequent human resources planning in the given organisation. Recruitment and selection criteria are defined on its basis. It has a significant impact on subsequent adaptation of employees, particularly to working and social conditions, when, on its basis, employees are familiarised with all future co-workers, not only the immediate ones. Job analysis has a not negligible role in education of employees, particularly in case of occurrence of new technology able to facilitate work. Last but not least, job analysis has a significant role in creation of safe working conditions and ergonomic environment, since the set of conditions affecting a person in the working process has an impact on their performance.
Ensuring of ergonomic environment in work performance has a positive effect not only on health of employees and their physical and psychical condition but, as the research proved, it also has a significant impact on economic results of the organisation (Stachová, 2012). As the given implies, in case job analysis is not elaborated, respectively it is elaborated inconsistently or during a long time, serious problems occur in all spheres of human resource management.

\section{CHARACTERISTICS OF THE RESEARCH}

The research was conducted over 2011 and 2012, always from February to May. The questionnaire was distributed to organisations with 50 and more employees. Our basic presumption upon specifying the target group given by the size of organisation from the viewpoint of minimum number of employees was that organisations with less than 50 employees do not have standardized and formally established approaches towards human resource management, and thus neither towards its individual functions. Collection, sorting and subsequent summarization of obtained information from the research were conducted from June to September each year. Mathematical and statistical methods were used upon processing of information, their analysis and comparison, and qualitative methods were subsequently used upon their identification and evaluation.

340 respondents participated in the $1^{\text {st }}$ and $2^{\text {nd }}$ phase of the research. Summary size structure of the interviewed organisations is provided in Table 1 , implying that organisations with the number of employees from 50 to 300 were most represented in the research each year.

Table 1. Size structure of the analysed organisations

\begin{tabular}{|c|c|c|c|c|}
\hline $\begin{array}{c}\text { Number of employees in the } \\
\text { organisation }\end{array}$ & $\mathbf{5 0 - 3 0 0}$ & $\mathbf{3 0 1 - \mathbf { 1 , 0 0 0 }}$ & $\mathbf{1 , 0 0 1 - \mathbf { 5 , 0 0 0 }}$ & over $\mathbf{5 , 0 0 0}$ \\
\hline Share of organisations in \% - 2011 & 70 & 21 & 7 & 2 \\
\hline Share of organisations in \% - 2012 & 72 & 20 & 6 & 2 \\
\hline
\end{tabular}

Source: own research

\section{ANALYSIS OF PRESENT STATE}

With regard to the fact that job analysis mainly provides information for creation and description of working positions, for specification of demands imposed on employees and for creation of their competence profile, our research focused on 
finding out whether organisations carry out job analysis, for which positions and in what time intervals, respectively for what reasons. As entity carrying out job analysis can significantly influence its result, we were also finding out who in organisations is in charge of carrying out of the analysis and what method of information collection is used for this purpose. In finding out of the focus of organisations on job analysis, we were also analysing awareness of managing employees in human resource management, who should participate in it but mainly initiate it. The results implied that organisations focus on this function only in approximately $60 \%$ (Table 2).

Table 2. Carrying out of job analysis

\begin{tabular}{|l|c|c|}
\hline \multirow{2}{*}{ Carrying out of job analysis } & \multicolumn{2}{|c|}{ Share of organisations in \% } \\
\cline { 2 - 3 } & $\mathbf{2 0 1 1}$ & $\mathbf{2 0 1 2}$ \\
\hline Yes, we carry it out & 59 & 62 \\
\hline No, we do not carry it out & 41 & 38 \\
\hline
\end{tabular}

Source: own research

In organisations carrying out job analyses, we subsequently focused on finding out the comprehensiveness of its carrying out, and thus we were finding out for which positions job analysis is conducted. Organisations were least concerned with managerial positions analyses (Table 3).

Table 3. Carrying out of job analysis for individual working positions

\begin{tabular}{|l|c|c|}
\hline \multirow{2}{*}{$\begin{array}{l}\text { Working positions for which } \\
\text { organisations carry out job analyses }\end{array}$} & \multicolumn{2}{|c|}{$\begin{array}{c}\text { Share organisations } \\
\text { in \% }\end{array}$} \\
\cline { 2 - 3 } & $\mathbf{2 0 1 1}$ & $\mathbf{2 0 1 2}$ \\
\hline Management & 60 & 56 \\
\hline Specialists & 66 & 69 \\
\hline Administrative employees & 63 & 70 \\
\hline Manual workers & 61 & 67 \\
\hline
\end{tabular}

In case organisations carry out job analysis, we were interested in what the impulse for that is, respectively in what intervals it is conducted. Organisations most often marked creation of new working positions as the impulse, and organisations carrying out the analysis regularly most often marked the yearly interval (Table 4).

Table 4. Reason for job analysis carrying out, respectively its frequency

\begin{tabular}{|l|c|c|}
\hline \multirow{2}{*}{$\begin{array}{l}\text { Reason for job analysis carrying } \\
\text { out, respectively its frequency }\end{array}$} & \multicolumn{2}{|c|}{$\begin{array}{c}\text { Share of organisations } \\
\text { in \% }\end{array}$} \\
\cline { 2 - 3 } & $\mathbf{2 0 1 1}$ & $\mathbf{2 0 1 2}$ \\
\hline Upon creation of working positions & 55 & 53 \\
\hline Upon change of job content & 45 & 45 \\
\hline Upon personnel audit & 24 & 24 \\
\hline Regularly: - yearly & 14 & 15 \\
- half - yearly & 8 & 4 \\
\hline Other & 4 & 2 \\
\hline
\end{tabular}

Source: own research

In finding out which employee, respectively department carries out job analysis in the organisation, we found out that a direct superior of the employee whose job is being analysed is most often involved in this activity (Table 5). 
Table 5. Performers of job analysis

\begin{tabular}{|l|c|c|}
\hline \multirow{2}{*}{ Who carries out job analysis } & \multicolumn{2}{|c|}{$\begin{array}{c}\text { Share of organisations } \\
\text { in \% }\end{array}$} \\
\cline { 2 - 3 } & $\mathbf{2 0 1 1}$ & $\mathbf{2 0 1 2}$ \\
\hline Direct superior & 78 & 84 \\
\hline Employee occupying the given position & 12 & 15 \\
\hline External agency & 10 & 9 \\
\hline $\begin{array}{l}\text { Department of human resource } \\
\text { management / personnel department }\end{array}$ & 10 & 8 \\
\hline
\end{tabular}

Source: own research

Method of carrying out an analysis has a significant impact on any analysis from the viewpoint of time as well as the viewpoint of quality level. Therefore, our research also focused on finding out what methods were used in job analysis. Organisations most often use the interview method (Table 6).

Table 6. Usage of individual methods in job analysis

\begin{tabular}{|l|c|c|}
\hline \multirow{2}{*}{ Methods used in job analysis } & \multicolumn{2}{|c|}{ Share of organisations in \% } \\
\cline { 2 - 3 } & $\mathbf{2 0 1 1}$ & $\mathbf{2 0 1 2}$ \\
\hline Interview & 62 & 60 \\
\hline Questionnaire & 43 & 27 \\
\hline Observation & 28 & 49 \\
\hline Other & 6 & 4 \\
\hline
\end{tabular}

Source: own research

\section{EVALUATION OF PRESENT STATE}

Job analysis is the key function of human resource management, which results from so called cross-sectional character of this function. The most essential fact in relation to job analysis is its need to carry it out before any activity from the sphere of human resource management functions, since its result has a significant impact on all these activities. The answers of organisations to question whether they deal with job analysis implied that approximately $40 \%$ of them do not carry out job analysis at all. Based on the aforementioned results, we can state that these organisations do not realise its importance. We were subsequently finding out whether the size of organisation has an impact on carrying out of job analysis. For this purpose, we compared this relationship in the form of a table
(Table 7) and we found out that the size of organisation has an impact on carrying out of job analysis. We suppose that this relationship is caused by several factors. One of them is the fact that bigger organisations have their mother organisation abroad and take over its habits, processes and norms, also regarding job analysis. We consider the fact that smaller companies, where the owner is also a personnel professional, do not realise this need as another significant factor. As these owners stated in the research: "I know the content of work my employees perform well and in detail, since I was performing it myself at the time of establishment of the organisation. Job analysis would only be additional work for me." In our opinion, these two factors have the most significant impact on carrying out of job analysis.

Table 7. Relationship comparison of the approach of organisations to carrying out of job analysis and the size of organisation

\begin{tabular}{|c|c|c|c|}
\hline \multirow{2}{*}{\multicolumn{2}{|c|}{ Share of organisations in \% }} & \multicolumn{2}{|c|}{$\begin{array}{l}\text { Organisations carrying } \\
\text { out job analysis }\end{array}$} \\
\hline & & 2011 & 2012 \\
\hline \multirow{4}{*}{ Size of organisation } & $50-300$ & 53 & 58 \\
\hline & $301-1,000$ & 68 & 66 \\
\hline & $1,001-5,000$ & 87 & 90 \\
\hline & over 5,000 & 100 & 100 \\
\hline
\end{tabular}


Within the research, we also focused on finding out whether organisations carry out job analysis comprehensively, i.e. for all employees or only for some categories (management, specialists, administrative employees, manual workers). The answers implied (Table 3 ) that only $35 \%$ of the interviewed organisations declaring carrying out of job analysis carried it out comprehensively for all employee categories in 2011, and this number even decreased to $28 \%$ in 2012. Most of organisations carry out the analysis only for several working positions.

Regarding organisations carrying out job analysis, we were interested in the reason, respectively frequency of carrying out of job analysis. Organisations mostly (more than 50\%) carry out the analysis upon creating of a working position. This answer is the most frequent, however organisations could mark more than one of the options, which resulted in the fact that some organisations are waiting for the audit, or a term when they normally carry out the analysis and do not carry it out flexibly when needed.

As far as creation of a new working position is concerned, it is necessary to define working tasks, rights and duties so that the given employee can carry them out effectively. It is therefore necessary to define competencies (education, abilities and attitude). Creation of a new working position is at the same time a process of creation of specific conditions for it, while respecting needs, rights and duties of other employees in organisational structure of the organisation. Creating of a working position needs to be dealt with almost constantly, in cases of changes in objectives of the organisation; change, respectively modification of used technologies; innovation implementation; change of offer on the labour market; as well as in many other cases (Koubek, 2006). The aforementioned implies the importance of job analysis in relation to the given situation, which is a reason why we consider passivity of organisations in such case as significantly negative also because of its relation to other human resource management functions, particularly the subsequent recruitment and selection of employees for newly-created working positions. $55 \%$ in 2011 and $53 \%$ in 2012 out of the whole analysed sample of 340 organisations answered positively, which represents only less than $25 \%$ in both years.

Similar negative result appears in the second option, where $45 \%$ of respondents stated in both years that they carry out the analysis in case of a change of job content, while it is necessary to point out mainly its interconnection with other function of human resource management education of employees, since only on the grounds of change of job content defined in advance is it possible to educate employees systematically and prepare them for the change. Practical experience points out the fact that the best results in the sphere of education are achieved when education of employees is conducted continuously. It results from the fact that if human resource management is supposed to fulfil demanding tasks related to formation of adequate working potential effectively and in accordance with goals of the organisation, a functional system of employee education, responding to constant changes of environment and leading towards enhancement of their performance has to be its component.

In finding out the frequency of job analysis, we arrived at a conclusion that approximately $10 \%$ of organisations carry out the analysis regularly with the minimum annual frequency and at the same time they deal with it upon creation of new working positions as well as upon change of job content. Such behaviour of organisations is considered as desired.

After finding out the reason and frequency of carrying out of job analysis in organisations, we were further finding out who carries it out. Organisations could mark more than one option (Table 5). Low figures (12\% - $15 \%$ ) in the option that the analysis is conducted by the employee occupying the given position were surprising in answers of organisations. It is due to the fact that the employee working at the analysed position is considered as the most significant source of information in job analysis. Such employee is most commonly able to point out insufficiencies, reveal problems as well as possibilities of streamlining of the job. This discrepancy was clarified after analysing of answers to question what methods organisations use in the analysis (Table 6). Organisations stated interview as the most preferred analysis method. Interconnection 
of this fact with the most frequent answer in identification of the analysis performer implies that $60 \%$ to $62 \%$ of organisations carry out job analysis through an interview between the employee working at the analysed position with their direct superior. The given fact clarifies the low figure stating that only $12 \%-15 \%$ of organisations use the employee occupying the given position to carry out the analysis (within the questionnaire completion, employees of the department of human resource management marked only a direct subordinate as the performer, not the employee at the analysed position at the same time. However, as long as superiors carry out job analysis through an interview it is obvious that the employee at the analysed position participates in it). This finding is considered as positive, since when the analysis is conducted by the superior with the subordinate, loss of information which the employee at the given position has does not occur, on the contrary, room occurs in such case for an immediate discussion between participants in the interview and searching for possibilities how to solve the found problem, respectively possibilities how to streamline performance at the given position. It is appropriate when such interview is combined with the questionnaire method. In such case, it is desired that employee working at the analysed position as well as their direct superior complete a questionnaire focused on job analysis in advance, while they both have a room to consider individual answers or mark facts necessary to discuss during the interview. In case it takes place regularly once, respectively twice a year, it is suitable to connect this interview with motivation, respectively carrier interview, since information found in job analysis can immediately be used in creation of education and carrier growth plans, or be interconnected with evaluation and subsequent remuneration of employees. Combined comparison of organisations using interview and questionnaire methods implied that these methods are concurrently used by only $30-33$ organisations, representing less than $10 \%$ of interviewed organisations (Table 8).

Table 8. Comparison of organisations carrying out the interview job analysis with organisations carrying out the questionnaire analysis

\begin{tabular}{|l|c|c|c|}
\hline \multirow{2}{*}{ Numbers of organisations in: } & \multicolumn{2}{|c|}{ Questionnaire job analysis } \\
\cline { 3 - 4 } & no & 52 & yes \\
\hline \multirow{2}{*}{ Interview job analysis 2011 } & yes & 93 & 24 \\
\cline { 2 - 4 } & no & 57 & $\mathbf{3 3}$ \\
\cline { 2 - 4 } Interview job analysis 2012 & yes & 96 & $\mathbf{3 0}$ \\
\hline
\end{tabular}

\section{CONCLUSIONS}

Job analysis can generally be characterized as a systematic process of collection, evaluation and summarization of information on individual works and preconditions of their performance. Collected information subsequently needs to be summarized in the form of job description and specification of requirements on the given employee, and its implementation in performance of the given work needs to be ensured. Justification and importance of job analysis mainly results from the fact that job analysis is the cross-section function of human resource management, which means that it has a direct impact on organisational structure creation and subsequent human resources planning in the organisation.
The research we conducted at School of Economics and Management in Public Administration in Bratislava in organisations operating in Slovakia implied that approximately $40 \%$ of organisations do not carry out job analysis at all, as well as the fact that only slightly more than $40 \%$ of interviewed organisations declaring that they carry out job analysis carry it out comprehensively for all working positions. The research implied that most of organisations only carry out the analysis for several working positions.

Practical justification of the given research part is predominantly seen in analysing of the behaviour of organisations operating in Slovakia towards directing and advancing in the sphere of human resource management. On the grounds of our 
presentation of collected results, managements of organisations have an opportunity to compare their own present states within the given sphere to states declared by interviewed organisations, and on its basis, to consider possibilities of its enhancement. We also consider as necessary to continue in this research so that individual approaches can be enhanced, modified, streamlined and developed on the grounds of new information obtained from the interviewed organisations.

\section{Acknowledgements}

The article is related to Grant Agencies of VSEMvs project, project No. 3/13, The Key Functions of Human resource management in the Context of Development of Organisations Operating in the Slovak Republic and Czech Republic.

\section{Works Cited}

Blštáková, J. (2009). How has the employees' appraisal system changed in Slovak companies over the last decade? Research results In Economics, Finance and Company Management, Bratislava: FPM, University of Economics in Bratislava, 2009 ISBN: 978-80-225-2808-5

Cagáňová, D., Čambál, M., \& Šujanová, J. (2010). Effective Intercultural Management - Way to High Performance of Global Corporations. Manager Forum (Vol.1). ISSN 1336-7773. p. $72-75$.

Kachaňáková, A., Nachtmanová, O., \& Joniaková, Z. (2011). Personal management. Bratislava: lura Edition. 2011. 235 p. ISBN: 978-80-8078-391-4.

Koubek, J. (2006). Human Resources Management. 3. edition, Prague: Management Press. 367 p. ISBN 80-7261-033-3.

Kravčáková, G. (2011). Work and Preconditions of Performing of Work of University Teachers. Inaugural Dissertation, Comenius University in Bratislava. p. 206.

Stachová K. (2012). Focus of Organisations Operating in Slovakia on Job Analysis In: Economics and Society. 13(1) ISSN 1335-7069. p. $88-97$.

Stasiak-Betlejewska, R., \& Piasecki, P. (2011). Analysis of Workers Satisfaction in Company Logistic Operator. Human Potential Management in a Company - Knowledge Increase, Trnava: AlimniPress. ISBN:978-80-8096-144-2. p. $33-42$.

Urbancová, H., \& Königová, M. (2010 July). Control and its role in the process of ensuring knowledge continuity. Journal of Modern Accounting and Auditing. 6(7). USA: David Publishing. ISSN 1548-6583. p. $38-45$.

Received for publication:

02.04 .2013

Revision received:

03.05 .2013

Accepted for publication:

12.05.2013

\section{How to cite this article?}

Style - APA Sixth Edition:

Stachova, K. (2013, 07 15). Job analysis as a cross-section function of human resource management. (Z. Čekerevac, Ed.) MEST Journal, 1(2), 127-135. doi:10.12709/mest.01.01.02.12 
Style - Chicago Fifteenth Edition:

Stachova, Katarína. "Job analysis as a cross-section function of human resource management."

Edited by Zoran Čekerevac. MEST Journal (MESTE) 1, no. 2 (07 2013): 127-135.

Style - GOST Name Sort:

Stachova Katarína Job analysis as a cross-section function of human resource management [Journal] = Key function of human resources management // MEST Journal / ed. Čekerevac Zoran. Belgrade : MESTE, 07 15, 2013. - 2 : Vol. 1. - pp. 127-135. - ISSN 2334-7058 (Online); ISSN 23347171.

Style - Harvard Anglia:

Stachova, K., 2013. Job analysis as a cross-section function of human resource management. MEST Journal, 15 07, 1(2), pp. 127-135.

Style - ISO 690 Numerical Reference:

Job analysis as a cross-section function of human resource management. Stachova, Katarína. [ed.] Zoran Čekerevac. 2, Belgrade : MESTE, 07 15, 2013, MEST Journal, Vol. 1, pp. 127-135. ISSN 23347058 (Online); ISSN 2334-7171. 